\title{
Variation in genetic traits of the lugworm Arenicola marina: temperature related expression of mitochondrial allozymes?
}

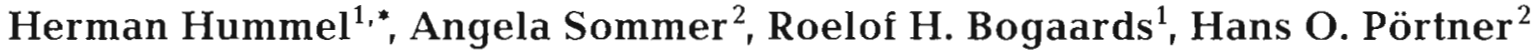 \\ 'Centre for Estuarine and Coastal Ecology, Netherlands Institute of Ecology, Vierstraat 28, 4401 EA Yerseke, The Netherlands \\ ${ }^{2}$ Alfred Wegener Institute for Polar and Marine Research, Columbusstr., D-27568 Bremerhaven, Germany
}

\begin{abstract}
Genetic traits of the lugworm Arenicola marina were determined for 4 Atlantic populations from France to Norway and compared with a population from the sub-arctic White Sea in Russia. Seven loci were analysed using horizontal starch gel electrophoresis. A low heteruzygosity 10.09 to $0.17)$ and a non-significant heterozygote deficiency were found in all populations. The genetic identity between lugworms of European Atlantic populations was high, whereas similarity of the Atlantic populations with the population from the White Sea was low. The gene flow between the Atlantic and the White Sea populations must be considered negligible, as deduced from the average high and significant gene differentiation $F_{\mathrm{ST}}$. In particular, differences in allele frequencies of glucose phosphate isomerase (Gpi) and phosphoglucomutase $(P g m)$ showed that the White Sea population differed significantly from the others. A very strong correlation existed between the frequency of the alleles of isocitrate dehydrogenases $2-A$ and $-B(I d h 2-A$ and $I d h 2-B)$ and the average water temperature. It is concluded that temperature had a selective influence on isocitrate dehydrogenase 2 , which, in contrast to isocitrate dehydrogenase 1 , was identified as a mitochondrial enzyme. These findings support the hypothesis that mitochondria play a key role in temperature adaptation and the adjustment of critical temperatures
\end{abstract}

KEY WORDS: Arenicola marina - Genetics - Geographic cline - Isozyme - Lugworm Polychaeta Temperature $\cdot$ Mitochondria

\section{INTRODUCTION}

Differences in the metabolic reaction to temperature changes have been observed between 2 populations of the lugworm Arenicola marina from the German North Sea and from the Russian White Sea (Sommer et al. 1997). The tolerance of both populations to temperature fluctuations is limited, as indicated by the existence of low and high critical temperatures $\left(\mathrm{Tc}_{1}\right.$ and $\mathrm{TC}_{\mathrm{II}}$ ), both of which are characterised by the onset of anaerobic metabolism. In White Sea lugworms these critical temperatures were shifted to lower values when compared with North Sea specimens. Additionally, the ability of North Sea lugworms to adapt to tem-

•E-mail: hummel@cemo.nioo.knaw.nl peratures beyond the critical temperatures was poor compared to that of White Sea lugworms (Sommer et al. 1996, 1997). The larger range of temperature fluctuations at the White Sea was seen as a reason for the higher adaptational capacity of the sub-polar lugworms.

The exact mechanisms enabling survival under extreme temperature conditions and causing an adaptive shift of the Tc are unknown. A hypothesis was developed that, among other mechanisms, Tc values are set by an adjustment of mitochondrial density and thus, aerobic capacity (Pörtner et al. 1997, Sommer et al. 1997). The differences in the ability to acclimate to temperature changes may, therefore, be linked to differences in the capacity to adjust mitochondrial density. This may either be explained as (phenotypic) acclimation of congenial populations to environmental temperatures or as (genetic) adaptation of remote pop- 
ulations (Nevo 1978). Statistical, biochemical and physiological correlates provide circumstantial evidence supporting the hypothesis that environmental heterogeneity can be a major factor in maintaining and structuring genetic variation in natural populations. However, direct experimental evidence establishing cause-effect relationships between ecophysiological and genetic structures is still sparse (e.g Hilbish et al 1982, Hoffmann \& Parsons 1994).

As a further step toward unravelling the differences in temperature acclimation in lugworms, whether it is phenotypic acclimation or genetic adaptation, the degree of relationship between the different populations of lugworms, from the North Sea and White Sea, was assessed by determination of the genetic constitution through electrophoretic isoenzyme analysis. For an identification of eventual geographic patterns in the genetic variability of the lugworm, some additional populations at more southern (warmer) and northern (sub-arctic) locations were sampled in the Oosterschelde (Netherlands), Gironde (France) and near Tromsø (Norway).

\section{MATERIAL AND METHODS}

At each sampling station (Fig. 1) lugworms were collected from intertidal flats between mean tidal level and low water level. The stations were located at: (1) France, Bay of Arcachon, $44^{\circ} 40.5^{\prime} \mathrm{N}, 1^{\circ} 11.0^{\prime} \mathrm{W}$, (2) The Netherlands, Oosterschelde sea arm, Yerseke,

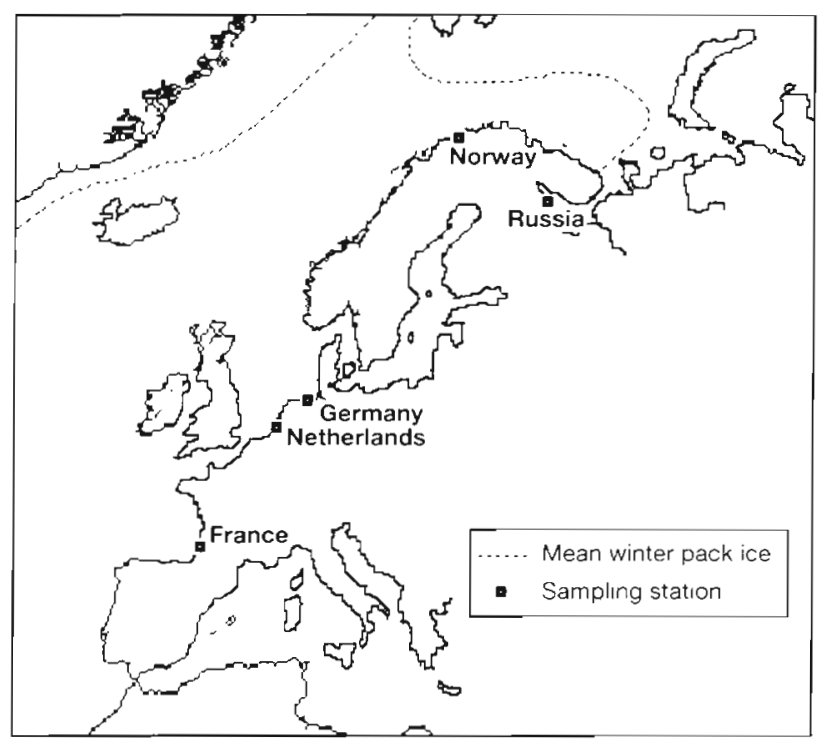

Fig. 1. Sampling stations in the Atlantic (France, Bay of Arcachon; The Netherlands, Oosterschelde sea arm; Germany, Wadden Sea near Bremerhaven; Norway. near Tromsø) and in the White Sea (Russia near Kartesh) $51^{\circ} 29.5^{\prime} \mathrm{N}, 4^{\circ} 03.5^{\prime} \mathrm{E}$, (3) Germany, Wadden Sea, $53^{\circ}$ $42^{\prime} \mathrm{N}, 8^{\circ} 35^{\prime} \mathrm{E}$, (4) Norway, Tromsø, 69 38.8' N, $18^{\circ} 54.3^{\prime} \mathrm{E}$ and (5) Russia, White Sea, Kandalaksha Bay, Chupa Inlet, $66^{\circ} 20.8^{\prime} \mathrm{N}, 33^{\circ} 35.8^{\prime} \mathrm{E}$.

Heads and tails of the worms were dissected. gonads and intestines were removed and only the body wall musculature was frozen in liquid nitrogen. The genetic constitution of the worms was examined using electrophoretic isoenzyme analysis of 7 loci according to Menken (1982) and Hummel et al. (1995): glucose phosphate isomerase (Gpi, E.C. 5.3.1.9), NADP-dependent isocitrate dehydrogenase 1 and 2 (Idh, E.C. 1.1.1.42), malate dehydrogenase (Mdh, E.C. 1.1.1.37), malic enzyme ( $M e$ E.C. 1.1.1.40), phosphogluconate dehydrogenase (Pgd, E.C. 1.1.1.44), and phosphoglucomutase (Pgm, E.C. 5.4.2.2). Fractions of the body walls (about $0.5 \mathrm{~g}$ ) of 40 to 80 lugworms were homogenized individually for a few seconds in about $0.2 \mathrm{ml}$ of gel buffer using a hand-made mortar and pestle. Electrophoresis was carried out in horizontal $12 \%$ starch gels (50\% Sigma, $50 \%$ Connaught) at a temperature of $0^{\circ} \mathrm{C}$. The buffer systems used were Tris-citric acid gel buffer ( 8 and $3 \mathrm{mM}$ resp.; $\mathrm{pH} \mathrm{6.7)}$ ) and Tris-citric acid electrode buffer $(0.223$ and $0.086 \mathrm{M}$ resp.; $\mathrm{pH}$ 6.3) The electrophoresis was performed for $5 \mathrm{~h}$ with a constant current of $100 \mathrm{~mA}$. Staining procedures used Bush B Tris-hydrochloric acid $(0.102 \mathrm{M}$; pH 8.4) according to Menken (1982)

The fastest allele is called A, the slower B, C, and so on. The data were analysed and statistically tested for allele frequencies, heterozygosity, conformance to Hardy-Weinberg equilibrium [fixation index $F_{15}$ approximating the deviation of the observed heterozygosity from the expected one $(\mathrm{Ho}-\mathrm{He}) / \mathrm{He}]$, coefficient of gene differentiation (fixation index $\mathrm{F}_{\mathrm{ST}}$; measure of differences in allele frequencies at each locus between populations) and genetic identities of genes between populations (standard genetic identity according to Nei 1975) by the Biosys computer programme (Swofford \& Selander 1981). Differences in allele frequencies and heterozygote frequencies of different groups were tested with the $\chi^{2}$ analysis (Sokal \& Rohlf 1995). All statistics were performed with Bonferroni correction. The $F$-statistics $F_{\mathrm{IS}}$ and $F_{\mathrm{ST}}$ are defined according to Nei (1977), and have properties similar to that of Wright's (1965) definition. $F_{I S}$ measures the deviation of genotype frequencies from Hardy-Weinberg proportions and the null hypothesis $F_{\mathrm{IS}}=0$ was tested for significance with $\chi^{2}=N F_{I S}{ }^{2}(b-1)$ and $b(b-1) / 2$ degrees of freedom ( $\mathrm{N}$ is the number of specimens analysed in the sub-populations, and $b$ is number of alleles) ( $\mathrm{Li}$ 1955). FIS measures the degree of genetic differentiation of sub-populations and was tested for significance with $\chi^{2}=2 \mathrm{~N} F_{\mathrm{ST}}(b-1)$ and $\mathrm{df}=(b-1)(\mathrm{n}-1)$ ( $\mathrm{n}$ is the number of sub-populations) (Workman \& Niswander 
1970). Computation of $F_{\mathrm{IS}}$ is not appropriate for almost-monomorphic loci (i.e. the dominant allele has a frequency $>0.8$ ) because of the predominant influence of rare alleles. These statistics were performed with Bonferroni correction, at a critical probability level of $a^{\prime}=0.05 / x$ ( $x$ is number of repetitions of the same test, i.e. 4 for $F_{\mid \mathrm{S}}$ and 8 for $F_{\mathrm{ST}}$; Sokal \& Rohlf 1995).

For preparation of mitochondria, about $1.5 \mathrm{~g}$ of body wall tissue was homogenized in $40 \mathrm{ml}$ buffer containing $40 \mathrm{mM}$ Tris ( $\mathrm{pH} 7.5$ ) and $0.55 \mathrm{M}$ glycine as well as $0.25 \mathrm{M}$ saccharose, $4 \mathrm{mM}$ EDTA and $0.2 \%$ bovine serum albumin. The homogenate was centrifuged at $4000 \times g$ for $15 \mathrm{~min}$ at $0^{\circ} \mathrm{C}$. Mitochondria were found in the pellet after a second centrifugation for $60 \mathrm{~min}$ at $16000 \times \mathrm{g}$. The pellets were further used for electrophoretic isoenzyme analysis and treated as the body wall sections described above.

\section{RESULTS AND DISCUSSION}

The loci Mdh, Pgd, Me and Idh1 were monomorphic according to the $5 \%$ criterion (Table 1). The other loci had a higher allelic variability, but the 2 most common alleles together had a frequency of 0.9 or more (Table 1 ). The average heterozygosity across the 7 loci was around 0.13 (Table 1). A trend toward heterozygote deficiency $\left(F_{1 S}=0.09\right)$ occurred, yet the deviations from Hardy-Weinberg equilibrium were, in all but 1 example ( $\mathrm{Pgm}$ in the Russian population), non-significant (Table 1). Such a heterozygote deficiency trend is a common, but not yet understood, phenomenon in marine invertebrates (Berger 1983, Singh \& Green 1984, Zouros 1987. Zouros \& Mallet 1989, Gaffney 1994).

The genetic diversity, as measured by heterozygosity, of the lugworm is low when compared to bivalves analysed in the same geographic territory with the same set of isoenzymes. In bivalves with a strong gene flow, Cerastoderma edule, Macoma
Table 1 Arenicola marina. Allele $(A-F)$ frequencies and measures of genetic variability in lugworm populations from the Atlantic (Nether.: The Netherlands) and the White Sea (see Fig. 1). N = number of specimens; for abbreviation of isoenzymes see 'Materials and methods'; $\mathrm{He}=$ expected heterozygosity; Ho $=$ observed heterozygosity; $F_{\mid S}=$ conformance to Hardy-Weinberg equilibrium, $F_{\mathrm{ST}}=$ gene differentiation; $\mathrm{n}$ alleles = average number of alleles. Bonferroni correction for tests on significance of $F_{i \mathrm{~S}}: a^{\prime}=a / 4$; Bonferroni correction for tests on significance of $F_{\mathrm{ST}}: d^{\prime}=a / 8 ; " p<0.05, \cdots p<0.01$, na: not applicable

\begin{tabular}{|c|c|c|c|c|c|c|c|c|}
\hline \multirow[b]{2}{*}{$M d h$} & \multirow[b]{2}{*}{ A } & \multirow{2}{*}{$\begin{array}{c}\text { France } \\
80\end{array}$} & $\begin{array}{c}\text { Nether } \\
80\end{array}$ & $\begin{array}{l}\text { Populatic } \\
\text { German } \\
\quad 80\end{array}$ & $\begin{array}{c}\text { Norway } \\
40\end{array}$ & $\begin{array}{c}\text { Russia } \\
80\end{array}$ & \multicolumn{2}{|c|}{$\begin{array}{c}F_{S T} \\
\text { All All-Russia } \\
\left.\text { [avg } F_{i S}\right]\end{array}$} \\
\hline & & & 0.063 & 0.063 & 0.025 & 0.000 & 0.024 & 0.016 \\
\hline & B & 0.988 & 0.938 & 0.931 & 0.975 & 1.000 & 0.023 & 0.014 \\
\hline & C & 0.006 & 0.000 & 0.006 & 0.000 & 0.000 & 0.004 & 0.003 \\
\hline \multicolumn{2}{|c|}{$A v g F_{S T}$} & & & & & & 0.023 & 0.015 \\
\hline \multicolumn{2}{|c|}{$\begin{array}{l}\text { Ho } \\
\text { He }\end{array}$} & $\begin{array}{l}0.025 \\
0.025\end{array}$ & $\begin{array}{l}0.125 \\
0.118\end{array}$ & $\begin{array}{l}0.138 \\
0.130\end{array}$ & $\begin{array}{l}0.050 \\
0.049\end{array}$ & $\begin{array}{l}0.000 \\
0.000\end{array}$ & & \\
\hline \multirow[t]{3}{*}{ Pgd } & $A$ & 0.050 & 0.019 & 0.056 & 0.013 & 0.000 & 0.018 & 0.011 \\
\hline & B & 0.950 & 0.975 & 0.938 & 0.988 & 1.000 & 0.018 & 0.011 \\
\hline & $D$ & 0.000 & 0.006 & 0.006 & 0.000 & 0.000 & 0.004 & 0.003 \\
\hline \multicolumn{2}{|l|}{$F_{\mathrm{ST}}$} & & & & & & 0.018 & 0.011 \\
\hline \multirow{2}{*}{\multicolumn{2}{|c|}{$\begin{array}{l}\mathrm{Ho} \\
\mathrm{He}\end{array}$}} & 0.100 & 0.050 & 0.125 & 0.025 & 0.000 & & \\
\hline & & 0.096 & 0.049 & 0.119 & 0.025 & 0.000 & & \\
\hline \multirow[t]{4}{*}{ Me } & A & 0.006 & 0.038 & 0.025 & 0.063 & 0.000 & 0.020 & 0.013 \\
\hline & B & 0.988 & 0.925 & 0.962 & 0.938 & 1.000 & 0.023 & 0.013 \\
\hline & C & 0.006 & 0.013 & 0.013 & 0.000 & 0.000 & 0.005 & 0.003 \\
\hline & $D$ & 0.000 & 0.025 & 0.000 & 0.000 & 0.000 & 0.020 & 0.019 \\
\hline \multirow{2}{*}{\multicolumn{2}{|c|}{$F_{\mathrm{ST}}$}} & & & & & & 0.020 & 0.013 \\
\hline & & 0.025 & 0.125 & 0.075 & 0.125 & 0.000 & & \\
\hline & 0.025 & 0.143 & 0.073 & 0.119 & 0.000 & & \\
\hline \multirow[t]{4}{*}{$P g m$} & A & 0.013 & 0.038 & 0.025 & 0.112 & 0.006 & 0.040 & 0.034 \\
\hline & $B$ & 0.988 & 0.944 & 0.925 & 0.837 & 0.287 & $0.414^{\circ}$ & 0.042 \\
\hline & C & 0.000 & 0.019 & 0.038 & 0.013 & 0.706 & $0.581^{*}$ & 0.011 \\
\hline & D & 0.000 & 0.000 & 0.013 & 0.038 & 0.000 & 0.021 & 0.019 \\
\hline & & & & & & $0.426^{\circ}$ & 0.034 \\
\hline Ho & & 0.025 & 0.063 & 0.100 & 0.275 & 0.287 & & \\
\hline & & 0.025 & 0.108 & 0.143 & 0.288 & 0.421 & & \\
\hline$F_{\text {IS }}$ [av & & na & na & na & na & $0.313 \cdots$ & [0.233] & na \\
\hline Gpi & A & 0.031 & 0.106 & 0.081 & 0.000 & 0.025 & 0.033 & 0.033 \\
\hline & B & 0.956 & 0.875 & 0.900 & 1.000 & 0.700 & $0.105^{\circ}$ & 0.038 \\
\hline & C & 0.013 & 0.013 & 0.019 & 0.000 & 0.000 & 0.006 & 0.004 \\
\hline & D & 0.000 & 0.000 & 0.000 & 0.000 & 0.269 & $0.227^{*}$ & 0.000 \\
\hline & $\mathrm{E}$ & 0.000 & 0.006 & 0.000 & 0.000 & 0.000 & 0.005 & 0.005 \\
\hline & $\mathrm{F}$ & 0.000 & 0.000 & 0.000 & 0.000 & 0.006 & 0.005 & 0.000 \\
\hline$F_{\text {ST }}$ & & & & & & & $0.113^{\circ}$ & 0.033 \\
\hline Ho & & 0.087 & 0.225 & 0.138 & 0.000 & 0.412 & & \\
\hline & & 0.085 & 0.224 & 0.184 & 0.000 & 0.440 & & \\
\hline$F_{\mathrm{IS}}[\mathrm{av}$ & & na & na & na & na & 0.056 & {$[0.070]$} & {$[0.082]$} \\
\hline$I d h 1$ & A & 0.006 & 0.013 & 0.006 & 0.000 & 0.013 & 0.003 & 0.003 \\
\hline & B & 0.994 & 0.962 & 0.981 & 1.000 & 0.988 & 0.011 & 0.013 \\
\hline & C & 0.000 & 0.025 & 0.013 & 0.000 & 0.000 & 0.013 & 0.012 \\
\hline$F_{\mathrm{ST}}$ & & & & & & & 0.010 & 0.011 \\
\hline Ho & & 0.013 & 0.050 & 0.025 & 0.000 & 0.025 & & \\
\hline $\mathrm{He}$ & & 0.013 & 0.073 & 0.037 & 0.000 & 0.025 & & \\
\hline ldh 2 & A & 0.669 & 0.531 & 0.469 & 0.237 & 0.100 & $0.175^{*}$ & $0.097^{\circ}$ \\
\hline & $B$ & 0.325 & 0.463 & 0.525 & 0.762 & 0.900 & $0.180^{*}$ & $0.100^{\circ}$ \\
\hline & C & 0.000 & 0.006 & 0.006 & 0.000 & 0.000 & 0.004 & 0.003 \\
\hline & D & 0.006 & 0.000 & 0.000 & 0.000 & 0.000 & 0.005 & 0.005 \\
\hline$F_{\mathrm{ST}}$ & & & & & & & $0.176^{\circ}$ & $0.098^{\circ}$ \\
\hline Ho & & 0.375 & 0.575 & 0.438 & 0.275 & 0.175 & & \\
\hline $\mathrm{He}$ & & 0.450 & 0.507 & 0.508 & 0.367 & 0.181 & & \\
\hline$F_{\mathrm{IS}}[\mathrm{av}$ & & 0.161 & -0.141 & 0.133 & 0.241 & n.a & {$[0.080]$} & {$[0.085]$} \\
\hline Avera & & & & & & & & \\
\hline & & & & & & & $0.205^{\cdots}$ & 0.059 \\
\hline Ho & & 0.093 & 0.173 & 0.148 & 0.107 & 0.129 & & \\
\hline $\mathrm{He}$ & & 0.103 & 0.175 & 0.171 & 0.121 & 0.152 & & \\
\hline$F_{I S}[\mathrm{av}$ & & 0.097 & 0.011 & 0.135 & 0.116 & 0.151 & {$[0.092]$} & {$[0.076]$} \\
\hline $\mathrm{n}$ allel & & 2.6 & 3.1 & 3.1 & 2.0 & 2.0 & & \\
\hline
\end{tabular}




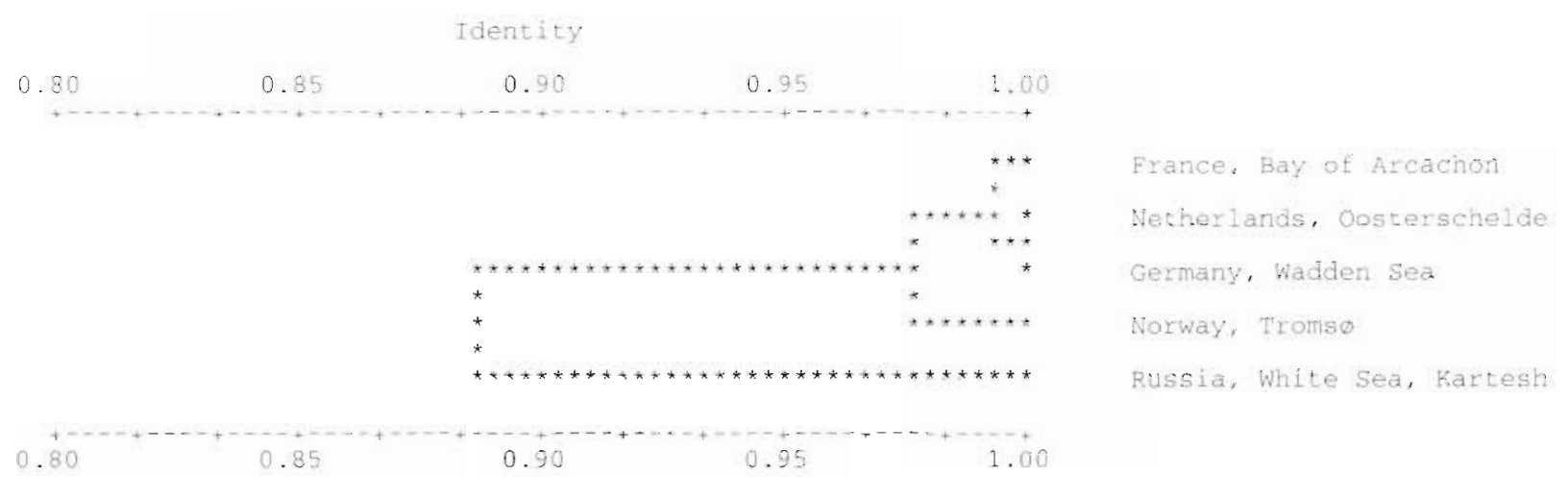

Fig. 2. Arenicola marina. Cluster analysis on the genetic identity between lugworm populations using the unweighted pair group methad (coefficient used: Nei's genetic identity)

balthica and Mytilus edulis, the heterozygosity ranged from 0.21 to 0.39 (vs 0.09 to 0.17 in lugworms) (Hummel et al. 1989, 1994, 1995). However, in the cockle Cerastoderma glaucum, a species with restricted gene flow inhabiting semi-isolated shallow non-tidal biotopes and estuaries, the heterozygosity was as low as in the lugworm, 0.09 to 0.17 (Hummel et al. 1994). The picture for other polychaetes is not as uniform as in the abovementioned bivalves; but, similar to the lugworms, the genetic diversity of other polychaetes seems to be lower in general. In Hediste limnicola, $H$. diversicolor and $H$. japonica heterozygosity ranged from 0.01 to 0.02 (Fong \& Garthwaite 1994), in Neanthes succinea from 0.02 to 0.04 (Abbiati \& Maltagliati 1992), and in 3 alvinellide polychaetes (Alvinella pompejana, A. caudata and Paralvinella grasslei) from 0.10 to 0.24 (Jollivet et al, 1995). Seven Nephtys species from different European locations proved even to be monomorphic in all 6 isoenzyme systems investigated (Schmidt \& Westheide 1994)

The genetic identities (Nei 1975) between (the Atlantic) lugworms from France, through The Netherlands and Germany, to Norway were high (Fig 2). The genetic identity of the Atlantic populations with the Russian White Sea population was low (0.89). A genetic identity below 0.9 might indicate that the populations belong to different subspecies (Avise 1974, Thorpe 1983). Confusion with the recently recognized black lugworm Arenicola defodiens (Cadman \& Nelson-Smith 1990, 1993) is thought to be of no importance. The allelic patterns distinctive for $A$. defodiens at the diagnostic loci Pgd and Gpi (Cadman $\&$ Nelson-Smith 1990) did not occur at all in our populations.

The differentiation between the Atlantic stations and the Russian station is also indicated by the average high and significant gene differentiation $F_{\mathrm{ST}}$ (on average 0.21 ) when including the Russian station, but low and non-significant $\left(F_{\mathrm{ST}}=0.06\right)$ when excluding the Russian station (Table 1). For marine bivalves with high gene flow, the average gene differentiation amounts to 0.01 to 0.03 between populations at geographic distances of hundreds of kilometres, and 0.04 to 0.06 at distances of thousands of kilometres (Skibinski et al. 1983, Dillon \& Manzi 1992, Grant et al. 1992, Sarver et al. 1992, Saavedra et al. 1993, Hummel et al. 1994, 1995). Similarly, the gene differentiation among the Atlantic populations, at mutual distances of several thousands of kilometres, amounted to 0.06 . In populations with limited gene flow, a much higher $F_{\text {ST }}$ can be found, e.g. 0.19 as found for Cerastoderma glaucum (Hummel et al. 1994). Therefore, gene flow between Arenicola marina populations from the Atlantic coasts can be considered to be strong, whereas gene flow between the White Sea and Atlantic populations must be considered negligible. Although $A$. marina has no pelagic larval stage (eggs are spawned at the sediment surface, hatching larvae immediately penetrate into the sediment), transport of eggs by currents and migration during post-larval stages has been observed frequently (Wolff 1973). Thus, transport by currents and migration are strong enough in the Atlantic to cause a considerable gene flow. The low or absent gene flow between the Atlantic and the White Sea is then probably due to the geographic and hydrographic isolation of the White Sea (Zenkevitch 1963) Very strong currents at the outer parts of the White Sea (in Gorlo and Voronca sounds) cause very violent turbulences of the whole water column. As a consequence the sea bed is covered with an extremely hard sediment which is poor in fauna and flora. Moreover, these tidal oscillations do not bring water of the Barents Sea into the White Sea. They only shift the masses of water within Gorlo sound, causing a separation of water masses and building a barrier for larvae or gametes. This seperation is probably so strong that even for the bivalve Macoma balthica, which has a pelagic larval stage of several weeks, a similar hampered gene flow was observed between the Atlantic and White Sea populations (Hummel et al. 1997). 


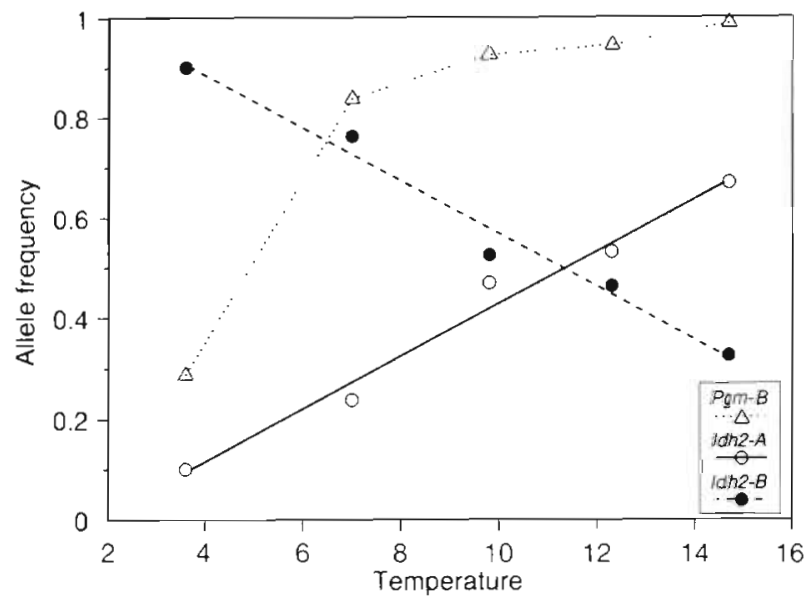

Fig. 3. Arenicola marina. Relation between allele frequencies of various enzymes in lugworms and the annual average temperature at the sampling locations [temperatures for France and The Netherlands from Hummel et al. 1995; for Germany from Becker 1981; for Norway from Treshnikov 1985; for Russia from $T$. Bek and $O$. Kozlova (based on daily measurements in 1987-1991, WSBS Poyakonda, Moscow State University, pers. comm. )]

The strong gene differentiation between the Atlantic and White Sea populations coincided with abrupt changes in the allele frequencies of Gpi and Pgm (Table 1, Fig. 3). A $\chi^{2}$ analysis of differences in allele frequencies of Gpi and Pgm showed that indeed only the White Sea population differed significantly from all others (Table 2). In contrast, the changes in allele frequencies of $I d h 2$ were more gradual when going from France to Russia (Table 2), as can be deduced from the gradually increasing $\chi^{2}$ with increasing distance between stations, marking, e.g., a significant difference between France and Norway but no sig-

Table 2. Statistical analyses $\left(\chi^{2}\right)$ of differences in allele frequencies between Arenicola marina populations for the loci Gpi, Pgm and $I d h 2 .{ }^{*} p<0.05, \cdots p<0.01$

\begin{tabular}{|c|c|c|c|c|}
\hline & he Netherl. & Germany & Norway & Russia \\
\hline \multicolumn{5}{|l|}{$G p i$} \\
\hline France & 4.05 & 2.01 & 1.81 & $26.26^{\circ}$ \\
\hline The Netherlands & & 0.87 & 5.45 & $29.08^{*}$ \\
\hline Germany & & & 4.29 & $27.89 \cdots$ \\
\hline Norway & & & & $15.00^{\circ}$ \\
\hline \multicolumn{5}{|l|}{$P g m$} \\
\hline France & 2.58 & 4.55 & 10.41 & $87.52 \cdots$ \\
\hline The Netherlands & & 1.78 & 5.76 & $81.99^{\circ}$ \\
\hline Germany & & & 5.31 & $76.82^{\circ}-$ \\
\hline Norway & & & & $54.40^{\circ}$ \\
\hline \multicolumn{5}{|l|}{ Idh 2} \\
\hline France & 3.20 & 6.58 & $20.54^{\cdots}$ & $55.75^{\circ}$ \\
\hline The Netherlands & & 0.62 & 9.80 & $35.24 \cdots$ \\
\hline Germany & & & 6.38 & $27.52 \cdots$ \\
\hline Norway & & & & 4.03 \\
\hline
\end{tabular}

nificant difference between Norway and the White Sea. A significant gene differentiation for Idh2 between the Atlantic populations was still found when the White Sea station was excluded (Table 1). The gradual geographic cline is most remarkable for the allele frequencies of $I d h 2-\mathrm{A}$ and $I d h 2-\mathrm{B}$ : a very strong correlation between the allele frequency and annual average water temperature existed, even when the Russian station was excluded (Fig. 3; r $=0.99, p<0.01$ for both comparisons).

Geographic clines in genotypes within a species, especially in a north-south direction, are a common phenomenon, and are mostly related to temperature and salinity (Koehn et al. 1976, 1980b, Endler 1977. Theisen 1978, Buroker 1983, Burton 1983, Rose 1984, Hoffman 1985, Dillon \& Manzi 1992, Hummel et al. 1995). The direct cause of such clines is not clearly known, although for leucine aminopeptidase $(L a p)$ in Mytilus edulis and Gpi in Metridium senile it has been shown that differential activities of allozymes are coupled to temperature or salinity (Koehn et al. 1976, 1980a, Koehn \& Siebenaller 1981, Hoffmann 1985). This may lead to genotype dependent differential selection, most probably during juvenile stages (Levinton \& Lassen 1978, Hilbish 1985). Some clines might also be caused by introgression of races or subspecies (Levinton \& Lassen 1978, Theisen 1978, Beaumont 1982, Koehn et al. 1984, Väinölä \& Varvio 1989). Yet, the genetic similarity of the Atlantic populations in this study clearly showed no difference at subspecies levels. So, the geographic cline found in this study is most probably an adaptive variation connected to temperature. Moreover, when a substantial migration between different populations exists, then the selective pressure of an environmental factor must be very strong, so that a specific allele can be fixed in the genome of a population (Pogson 1987). Since gene flow is strong between the Atlantic populations $\left(F_{\mathrm{ST}}=0.06\right)$, we can conclude that the selective pressure of temperature on the Idh loci must be considerable.

The electrophoretic isoenzyme analysis of the mitochondrial fraction identified $I d h 2$ to be a mitochondrial enzyme, whereas Idh 1 seems to be found in the cytosol. Further study revealed that latitudinal cold adaptation in Arenicola marina is linked to mitochondrial proliferation and an increase in the activity of cytochrome oxidase (A. Sommer \& H. Pörtner unpubl.) suggesting that mitochondria are an important site of temperature adaptation. This finding agrees with the picture arising from studies in cold ocean fish (Guderley 1997) and suggests that cold adaptation in general appears to be achieved by an increase in mitochondrial density as well as in oxidative capacity of individual mitochondria. This phenomenon led to the general hypothesis that changes in the density and functional properties of 
mitochondria are involved in setting the critical temperatures as the upper and lower limits of temperature tolerance (Sommer et al. 1997, Pörtner et al. 1997).

Expression of different $I d h 2$ isoenzymes with changing temperature may play an important role in this context. Idh has a central role in regulating the flow through the citric acid cycle (Stryer 1990), and therewith in metabolic regulation. Nothing is known about the differences in kinetic properties between the 2 isoforms Idh2-A and -B. However, these differences should optimize function at the respective temperatures and may involve a maintenance of $K_{\mathrm{m}}$ values and maximum velocity at low temperatures. Together with. mitochondrial proliferation and the rise in aerobic capacity this could explain the observed shift in critical temperatures at the whole-animal level (Sommer et al. 1996, 1997, Sommer \& Pörtner unpubl.).

In conclusion, the genetic constitution of the specimens studied showed that the genetic identity for the lugworm in European Atlantic populations is high, whereas the similarity with a population from the White Sea is low. Both geographic and hydrographic isolation of the White Sea as well as average water temperatures seem to influence the genetic constitution of the populations. Whereas the expression of Gpi and Pgm seems to be influenced by geographic and hydrographic isolation, the expression of $I d h 2$ isoforms is predominantly influenced by temperature.

Acknowledgements. Collection of specimens from France and Norway was made possible by funds from The Netherlands Marine Research Foundation (SOZ, presently Geosciences Foundation GOA; within the programme for FrenchDutch cooperation), UNESCO-COMAR, Paris, and from the International Association for the Promotion of Cooperation with Scientists from the Independent States of the former Soviet Union (INTAS project 94-391). We thank S. Cochrane and Akvaplan-Niva for taking samples from tidal flats near Tromsø and G. Bachelet for help in taking samples from the Bay of Arcachon. Isolation of mitochondria reported in this paper was supported by K. Tschischka, Alfred Wegener Institute, and is gratefully acknowledged. NIOO-CEMO communication no. 23235. Alfred-Wegener-Institute publication no. 1334 .

\section{LITERATURE CITED}

Abbiati M. Maltagliati F (1992) Genetic population structure of Neanthes succinea (Polychaeta:Nereididae). J Mar Biol Assoc UK 72:511-517

Avise JC (1974) Systematic value of electrophoretic data. Syst Zool 23:465-481

Beaumont AR (1982) Geographic variation in allele frequencies at three loci in Chlamys opercularis from Norway to the Brittany coast. J Mar Biol Assoc UK 62:243-261

Becker GA (1981) Beitrage zur Hydrogaphie und Wärmebilanz der Nordsee. Deutsche Hydrogr Zeitschr 34:167-262

Berger EM (1983) Population genetics of marine gastropods and bivalves. In: Russell-Hunter WD (ed) The mollusca, Vol 6. Ecology. Academic Press, Orlando, p 563-596
Buroker NE (1983) Population genetics of the American oyster Crassostrea virginica along the Atlantic coast and the Gulf of Mexico. Mar Biol 75:99-112

Burton RS (1983) Protein polymorphism and genetic differentiation of marine invertebrate populations (Review). Mar Biol Lett 4:193-206

Cadman PS, Nelson-Smith A (1990) Genetic evidence for two species of lugworm (Arenicola) in South Wales. Mar Ecol Prog Ser 64:107-112

Cadman PS, Nelson-Smith A (1993) A new species of lugworm: Arenicola defodiens sp. nov. J Mar Biol Assoc UK 73:213-223

Dillon RT, Manzi JJ (1992) Population genetics of the hard clam, Mercenaria mercenaria, at the Northern limit of its range. Can J Fish Aquat Sci 49:2574-2578

Endler JA (1977) Geographic variation, speciation, and clines Princeton University Press, Princeton

Fong PP, Garthwaite RL (1994) Allozyme electrophoretic analysis of the Hediste limnicola $-H$. diversicolor $-H$. japonica species complex (Polychaeta: Nereidae). Mar Biol 118:463-470

Gaffney PM (1994) Heterosis and heterozygote deficiencies in marine bivalves: more light? In: Beaumont AR (ed) Genetics and evolution of aquatic organisms. Chapman \& Hall, London, p 146-153

Grant WS, Schneider AC, Leslie RW, Cherry MI (1992) Population genetics of the brown mussel Perna perna in southern Africa. J Exp Mar Biol Ecol 165:45-58

Guderley H (1997) Temperature and growth rates as modulators of the metabolic capacities of fish muscle. In: Pörtner HO, Playle R (eds) Cold ocean physiology. Cambridge University Press, Cambridge (in press)

Hilbish TJ (1985) Demographic and temporal structure of an allele frequency cline in the mussel Mytilus edulis. Mar Biol 86:163-172

Hilbish TJ, Deaton LE, Koehn RK (1982) Effect of allozyme polymorphism on regulation of cell volume. Nature 298 : $688-689$

Hoffmann RJ (1985) Thermal adaptation and the properties of phosphoglucose isomerase allozymes from a sea anemone. In: Gibbs PE (ed) Proc 19th Eur Mar Biol Symp. Cambridge University Press, Cambridge, p 505-514

Hoffmann AA, Parsons PA (1994) Evolutionary genetics and environmental stress. Oxford Science Publications, Oxford University Press, Oxford

Hummel $H_{1}$ Bogaards RH, Amiard-Triquet $C$, Bachelet $G$, Desprez M, Marchand J, Sylvand B, de Wit $Y$, de Wolf $L$ (1995) Uniform variation in genetic traits of a marine bivalve related to starvation, pollution and geographic clines. J Exp Mar Biol Ecol 191:133-150

Hummel H, Bogaards R, Bek T, Polishchuk L, Amiard-Triquet C, Bachelet $G$, Desprez M, Strelkov P, Sukhotin A, Naumov A, Dahle S, Denisenko S, Gantsevich M, Sokolov K, de Wolf L (1997) Sensitivity to stress in the bivalve Macoma balthica from the most northern (Arctic) to the most southern (French) populations: low sensitivity in Arctic populations because of genetic adaptations? Hydrobiologia (in press)

Hummel H, Bogaards RH, de Wolf L, Wijnholds JA (1989) The interrelation of length, age and heterozygosity in Mytilus edulis in the delta area of the Netherlands. In: Aldrich JC (ed) Phenotypic responses and individuality in aquatic environments. JAPAGA Ashford Co, Wicklow, Ireland, p 65-71

Hummel $H$, Wolowicz M, Bogaards RH (1994) Genetic variability and relationships for populations of Cerastoderma edule and of the C. glaucum complex. Neth $J$ Sea Res 
33:81-89

Jollivet D, Desbruyères D, Bonhomme F, Moraga D (1995) Genetic differentiation of deep-sea hydrothermal vent alvinellid populations (Annelida: Polychaeta) along the East Pacific Rise. Heredity 74:376-391

Koehn RK, Bayne BL, Moore MN, Siebenaller JF (1980a) Salinity related physiological and genetic differences between populations of Mytilus edulis. Biol $\mathrm{J}$ Linn Soc $14: 319-334$

Koehn RK, Hall JG, Innes DJ, Zera AJ (1984) Genetic differentiation of Mytilus edulis in eastern North America. Mar Biol 79:117-126

Koehn RK, Milkman R, Mitton JB (1976) Populatıon genetics of marine pelecypods. IV. Selection, migration and genetic differentiation in the blue mussel Mytilus edulis. Evolution 30:2-32

Koehn RK, Newell RIE, Immermann F (1980b) Maintenance of an aminopeptidase allele frequency cline by natural selection. Proc Natl Acad Sci USA. 77.5385-5389

Koehn RK, Siebenaller JF (1981) Biochemical studies of aminopeptidase polymorphism in Mytzlus edulis. II. Dependence of reaction rate on physical factors and enzyme concentration. Biochem Genet 19;1143-1162

Levinton JS, Lassen HH (1978) Selection, ecology and evolutionary adjustment within bivalve mollusc populations. Phil Trans R Soc Lond, Ser B 284:403-415

Li CC (1955) Population genetics. University of Chicago Press, Chicago

Menken SBJ (1982) Biochemical genetics and systematics of small ermine moths (Lepidoptera, Yponomeutidae). Z Zool Syst Evolutionsforsch 20:131-143

Nei M (1975) Molecular population genetics and evolution. North Holland Pub] Co, Amsterdam

Nei M (1977) F-statistics and analysis of gene diversity in subdivided populations. Ann Hum Genet 41:225-233

Nevo E (1978) Genetic variation in natural populations: patterns and theory. Theor Pop Biol 13:121-177

Pogson GH (1987) Constraints on the genetic process of biochemical adaptation. Can J Zool 66:1139-1145

Pörtner HO, Hardewig 1, Sartoris FJ, van Dijk P (1997) Energetic aspects of cold adaptation: critical temperatures in metabolic, ionic and acid-base regulation? In: Pörtner HO, Playle R (eds) Cold ocean physiology. Cambridge University Press (in press)

Rose RL (1984) Genetic variation in the oyster, Crassostrea virginica (Gmelin), in relation to environmental variation. Estuaries 7:128-132

Saavedra C, Zapata C, Guerra A, Alvarez G (1993) Allozyme variation in European populations of the oyster Ostrea edulis. Mar Biol 115:85-95

Sarver SK, Landrum MC, Foltz DW (1992) Genetics and taxonomy of ribbed mussels (Geukensia spp.). Mar Biol 113:385-390

Schmidt $H$, Westheide W (1994) Isozymes and general protein patterns as taxonomic markers in the taxon Nephtyidae (Annelida, Polychaeta). Mar Biol 119:31-38

Singh SM, Green RH (1984) Excess of allozyme homozygosity

Editorial responsibility: Otto Kinne (Editor),

Oldendorf/Luhe, Germany in marine molluscs and its possible biological significance Malacologia 25:569-581

Skibınskı DOF, Beardmore JA, Cross TF (1983) Aspects of the population genetics of Mytilus (Mytilidae; Mollusca) un the British Isles. Biol J Linn Soc 19:137-183

Sokal RR, Rohlf FJ (1995) Biometry. Freeman \& Co, New York

Sommer A, Hummel H, Pörtner HO (1996) Adaptation of Arenscola marina to changing temperatures: a comparison of boreal and subpolar populations. Verh Dtsch Zool Ges $89: 186$

Sommer A, Klein B, Pörtner HO (1997) Temperature induced anaerobiosis in two populations of the polychaete worm Arenicola marina (L.). J Comp Physiol B 167:25-35

Stryer L (1990) Biochemie. Spektrum der Wissenschaft. Spektrum der Wissenschaft Verlag GmbH, Heidelberg, p 406-409

Swofford DL, Selander RB (1981) Biosys-1: a Fortran program for the comprehensive analysis of electrophoretic data in population genetics and systematics. J Heredity 72 : $281-283$

Theisen BF (1978) Allozyme clines and evidence of strong selection in three loci in Mytilus edulis L. (Bivalvia) from Danish waters. Ophelia 17:135-142

Thorpe JP (1983) Enzyme variation, genetic distance and evolutionary divergence in relation to levels of taxonomic separation. In: Oxford GS, Rollinson D (eds) Protein polymorphism: adaptive and taxonomic significance. Academic Press, London, p 131-152

Treshnikov AF (1985) Atlas of the Arctic. GYGK (Soviet Ministry of Geodesy and Cartography), Moscow

Väinölä R, Varvio SL (1989) Biosystematics of Macoma balthica in northwestern Europe. In: Ryland JS, Tyler PA (eds) Reproduction, genetics and distributions of marine organisms. Olsen \& Olsen, Fredensborg, p 309-316

Wolff WJ (1973) The estuary as a habitat. An analysis of data on the soft-bottom macrofauna of the estuarine area of the rivers Rhine, Meuse, and Scheldt. Zoologische Verhandelingen, No. 126. Brill, Leiden

Workman PL, Niswander JD (1970) Population studies on southwestern Indian tribes. II. Local genetic differentiation in the Papago. Am J Hum Gen 22:24-49

Wright S (1965) The interpretation of population structure by F-statistics with special regard to systems of mating. Evolution 19:395-420

Zenkevitch L (1963) Biology of the seas of the U.S.S.R. George Allen \& Unwin Ltd, London, p 181-184

Zouros $\mathrm{E}$ (1987) On the relation between heterozygosity and heterosis: an evaluation of the evidence from marine mollusks. In: Rattazi MC, Scabdalios JG, Whitt GS (eds) Isozymes: current topics in bjological and medical research, Vol 15. Genetics, development, and evolution. Liss Inc, New York, p 255-270

Zouros E, Mallet AL (1989) Genetic explanations of the growth/heterozygosity correlation in marine mollusks. In: Ryland JS, Tyler PA (eds) Reproduction, genetics and distribution of marine organisms. Olsen \& Olsen, Fredensborg, p 317-324

Submitted: June 30, 1997; Accepted: September 22, 1997

Proofs received from author(s): November 10, 1997 